\title{
IMPLEMENTASI PENGGUNAAN METODE RESITASI TERHADAP MINAT \\ MAHASISWA UNTUK BERKOPERASI \\ PADA MATA KULIAHKOPERASI
}

\author{
Meyta Pritandhari \\ Program Studi Pendidikan Ekonomi FKIP Universitas Muhammadiyah Metro \\ meyta.pritandhari@gmail.com
}

\begin{abstract}
Abstrak
Penelitian ini merupakan penelitian yang menggunakan pendekatan deskriptif kualitatif. Penelitian ini dilakukan pada mahasiswa program studi pendidikan ekonomi untuk mengetahui implementasi penggunaan metode resitasi terhadap minat mahasiswa untuk berkoperasi. Peneliti yang merupakan dosen pengajar pada program studi pendidikan ekonomi, menemukan permasalahan bahwa pada mata kuliah koperasi yang ditempuh mahasiswa semester lima ternyata masih banyak mahasiswa yang belum memiliki jiwa koperasi.Pembelajaran mata kuliah koperasi menggunakan metode resitasi yaitu pemberian tugas mandiri diluar jam pelajaran di kampus. Teknik pengumpulan data pada penelitian ini dengan cara observasi, wawancara, dokumentasi, foto dan tes. Dari tugas observasi langsung dan wawancara ternyata mahasiswa menunjukkan respon yang positif. Ketika mahasiswa diminta mempertanggungjawabkan hasil observasi dan wawancara yang telah dilakukan ternyata mereka dengan lengkap dan antusias menceritakan hasil yang mereka peroleh. Hal ini menunjukkan minat mahasiswa untuk mengenal lebih jauh tentang koperasi semakin baik. Selain itu, pemberian tugas lainnya adalah mahasiswa diminta membuat sebuah Koperasi Simpan Pinjam (KSP) per kelas.
\end{abstract}

Kata kunci: Resitasi, Minat mahasiswa

\section{PENDAHULUAN}

Indonesia merupakan salah satu Negara yang jumlah penduduknya padat. Seiring bertambahnya jumlah penduduk, angka pengangguran makin bertambah. Banyak masyarakat usia produktif yang bingung mencari pekerjaan. Bahkan banyak masyarakat yang sudah memiliki ijazah masih bingung dan belum mendapatkan pekerjaan. Ini merupakan suatu masalah yang akan berdampak terhadap perekonomian suatu negara. Oleh karena itu, pemerintah diharapkan dapat menuntun masyarakat untuk dapat kreatif menciptakan lapangan pekerjaan dan bukan sebagai pencari kerja. Dalam hal ini, mahasiswa sebagai agen perubahan dapat membantu pemerintah untuk mencari solusi masalah ini.

Masyarakat Ekonomi Asean (MEA) memiliki pola mengintegrasikan ekonomi ASEAN dengan cara membentuk sistem perdagangan bebas atau free trade antara negara-negara anggota ASEAN. Para anggota ASEAN termasuk Indonesia telah menyepakati suatu perjanjian Masyarakat 
Ekonomi ASEAN tersebut. Dengan adanya MEA, masyarakat Indonesia dituntut untuk dapat bersaing dengan negara lain. Sebagai bagian dari masyarakat peran mahasiswa sangat diperlukan dalam menghadapi MEA ini. Mahasiswa perlu dibekali pengetahuan dan keterampilan yang dapat berdaya saing secara global. Mahasiswa diharapkan dapat membuat inovasi kegiatan dalam bidang ekonomi.

Pendidikan ekonomi merupakan salah satu program studi IPS dimana program studi ini berupaya untuk mengeluarkan lulusan yang berkualitas dalam bidang pendidikan ekonomi. Program studi ini didukung juga dengan mata kuliah koperasi yang termasuk dalam mata kuliah pilihan yang harus ditempuh oleh mahasiswa pendidikan ekonomi. Dalam mata kuliah ini, mahasiswa diharapkan mampu mengerti arti penting koperasi dan menumbuhkan jiwa untuk berkoperasi kepada mahasiswa. Pembelajaran dalam mata kuliah ini menggunakan metode resitasi yaitu pemberian tugas kepada mahasiswa. Tugas yang diberikan adalah menyangkut materi yang telah diajarkan dan melakukan observasi terhadap koperasi -koperasi yag ada di sekitar daerah tempat tinggal mahasiswa. Setelah itu mahasiswa diharapkan dapat mampu mengaitkan teori yang telah dipelajari dengan observasi yang telah mereka lakukan. Pemberian tugas (resitasi) dengan langsung datang ke koperasi-koperasi diharapkan dapat menumbuhkan minat mahasiswa untuk berkoperasi.

\section{KAJIAN PUSTAKA}

\section{MetodeResitasi}

Proses pembelajaran yang baik harus ada interaksi antara dosen dengan mahasiswa interaksi disini berupa proses edukasi tidak hanya menyampaikan pesan materi ajar melainkan juga menanamkan sikap dan nilai terhadap diri mahasiswa yang sedang belajar. Salah satu unsure dalam proses pembelajaran adalah metode resitasi. Metode resitasi adalah metode yang dapat melibatkan mahasiswa secara aktif, mandiri dan bertanggungjawab dalam proses pembelajaran.

Menurut Sanjaya (2009:145) metode adalah carayang digunakan untuk mengimplementasikan rencana yang sudah disusun dalam kegiatan nyata agar tujuan yang telah disusun tercapai secara optimal. Sedangkan menurut Djamarah dan Zain (2013:96) menyatakan bahwa: metode resitasi/tugasa dalah penyajian bahan dimana dimana guru memberikan tugas tertentu agar siswa melakuka nkegiatan belajar.

Salah satu faktor yang mempengaruhi hasil belajar adalah metode pembelajaran guru. Metode pengajaran yang digunakan 
oleh guru harus disesuaikan dengan mata pelajaran yang akan disampaikannya, apakah metode tersebut sesuai ataukah sebaliknya. Menurut Djamarah dan Zain (2013:85)“tugas dan resitasi merangsang anak untuk aktif belajar, baik secara individu maupun secara kelompok". Metodeini diberikan karena dirasakan bahan pelajaran terlalu banyak, sementara waktu sedikit. Artinya, banyaknya bahanyang tersedia dalam waktu kurang seimbang. Agar bahan pelajaran selesai sesuai batas waktu yang ditentukan maka metode inilah yang biasanya guru gunakan untuk mengatasinya.

Berdasarkan pendapat para ahli dapat disimpulkan bahwa metode resitasi adalah cara belajar yang dilakukan dengan memberikan tugas khusus kepada mahasiswa untuk mengerjakan suatu materi yang telah diajarkan di luar jam belajar.

Metode pembelajaran yang diterapkan dalam penelitian ini adalah metoderesitasi. Menurut Djamarah dan Zain (2013:86) langkah-langkah yang harus diikuti dalam penggunaan metode tugas atau resitasiyaitu:

1) FasePemberian Tugas

Tugas yang diberikan kepada siswa hendaknya mempertimbangkan:

a) Tujuan yang akan dicapai.

b) Jenis tugas yang jelas dan tepat sehingga anak mengerti apa yang ditugaskan tersebut.

c) Sesuai dengan kemampuan siswa.

d) Adapetunjuk atau sumber yang dapat membantu pekerjaan siswa.

Sediakan waktu yang cukup untuk mengerjakan tugas tersebut.

2)Fase Pelaksanaan Tugas

a) Diberikan bimbingan/pengawasan oleh guru.

b) Diberikan dorongan sehingga anak mau bekerja.

c) Diusahakan/dikerjakan oleh siswa sendiri tidak menyuruh orang lain.

d) Dianjurkan agar siswa mencatat hasil-hasil yang diperoleh dengan baik dan sistematik.

3) Fase Mempertanggunjawabkan Tugas

Hal yang harus dikerjakan pada fase ini adalah :

a) Laporan siswabaik lisan/tertulis dari apa yang telah dikerjakannya.

b) Adatanyajawab/diskusi kelas.

c) Penilaian hasil pekerjaan siswa baik dengan tes maupun non tesatau cara lain

Meto deresitasi ini terdiri dari tiga fase, antara lain: guru memberitugas, siswa melaksanakan tugas (belajar) dansiswa mempertanggungjawabkan apa yang telah dipelajari. Pada intinya metode 
resitasi adalah samahalnya dengan penugasan dimana siswa mendapatkan tugas dari guru untuk dikerjakan, kemudian mempertanggungjawabkannya supaya siswa dapat memahami materi terkait dengan tugas tersebut.

\section{Minat Mahasiswa Untuk \\ Berkoperasi}

Minat adalah suatu perasaan senang terhadap sesuatu dan menganggap sesuatu itu lebih baik dari yang lain. Menurut Djamarah dan Zain (2013:132) "minat adalah kecenderungan yang menetap untuk memperhatikan dan mengenang beberapa aktivitas. Seseorang yang berminat terhadap aktivitas akan memperhatikan aktivitas itu secara konsisten dengan rasa senang." Sedangkan menurut Slameto (2010:180) menyatakan bahwa "Minat adalah suatu rasa lebih suka dan rasa ketertarikan pada suatu hal atau aktivitas, tanpa ada yang menyuruh.”

Sedangkan menurut Surya (2004: 65) mengenai jenis minat, menurutnya minat dapat dikelompokkan menjadi 3 jenis, yaitu sebagai berikut:

1) Minat volunter adalah minat yang timbul dari dalam diri siswa tanpa ada pengaruh luar.

2) Minat involunter adalah minat yang timbul dari dalam diri siswa dengan pengaruh situasi yang diciptakan oleh guru
3) Minat nonvolunter adalah minat yang ditimbulkan dari dalam diri siswa secara dipaksa atau dihapuskan.

Minat mahasiswa dalam menjalankan sebuah koperasi masih rendah. Hal ini ditunjukkan dengan kurangnya partisipasi mahasiswa dalam kegiatan praktikum koperasi. Hanya ada beberapa mahasiswa yang memiliki jiwa koperasi, sementara mahasiswa yang lain hanya sebagai pengikut setia mahasiswa yang aktif. Hal ini menjadi salah satu masalah yang harus dibenahi oleh dosen sebagai pengampu mata kuliah. Melalui pemberian tugas (resitasi) oleh dosen kepada mahasiswa diharapkan mampu menumbuhkan minat involunter yaitu minat yang timbul dari dalam diri mahasiswa yang diciptakan oleh guru, sehingga minat yang tercipta bukan hanya sekedar paksaan.

Mahasiswa adalah salah satu agen perubahan. Mahasiswa dapat membuat perubahan yang positif maupun perubahan negatif. Salah satu tugas dari seorang dosen adalah mengajar. Tanggung jawab dosen dalam mengajar bukan hanya sekedar memberikan materi kognitif saja. Namun, dosen dapat mengajarkan aspek lain yang berkaitan dengan kegiatan yang menunjang kegiatan pembelajaran. Contohnya dalam mengajar mata kuliah koperasi, dosen tidak hanya dituntut untuk menjelaskan teori-teorinya saja. Dosen dapat mengajarkan dan menumbuhkan 
minat mahasiswa dalam berkoperasi akan menjadi hal yang lebih baik. Dengan demikian, mahasiswa dapat menjadi agen perubahan yang sifatnya positif.

Mahasiswa pendidikan ekonomi dituntut untuk memiliki pemikiran yang kreatif dalam segala hal. Semua mata kuliah yang telah diajarkan diharapkan dapat diimplementasikan dalam dunia nyata. Salah satu mata kuliah yang diharapkan dapat diimplementasikan adalah mata kuliah koperasi. Pembelajaran dalam mata kuliah koperasi bukan hanya sekedar mempelajari teori tentang koperasi saja, namun dalam mata kuliah ini ada kegiatan praktikum yaitu membuat Koperasi Simpan Pinjam (KSP) mahasiswa. Kegiatan mahasiswa dalam membuat koperasi yang masih sederhana diharapkan dapat merangsang minat mahasiswa dalam berkoperasi.

\section{METODE PENELITIAN}

Penelitian inidilakukan di Prodi Pendidikan Ekonomi SemesterV (lima) Universitas Muhammadiyah Metro. Penelitian ini menggunakan metode penelitian deskriptif dengan pendekatan analisis kualitatif, yaitu mendeskripsikan datayang terkumpul kedalam kalimatkalimat yang memiliki arti lebih mendalam, karena menggambarkan secara tepat individu, keadaan, gejala, atau kelompok tertentu, guna menentukan frekuensi adanya hubungan antara satu gejala dengan gejalalainnya.

Menurut Moleong

(2007:6)

"Penelitian kualitatif adalah penelitian yang bermaksud untuk memahami fenomena tentang apa yang dialami oleh subyek penelitian misalnya: perilaku, persepsi, motivasi, tindakan, dan lain lain, secara holistik, dan dengan cara deskripsi dalam bentuk kata-kata dan bahasa, pada suatu konteks khusus yang alamiah dan dengan memanfaatkan berbagai metode alamiah"

Ditinjau dari apek yang diteliti, penelitian ini merupakan studi kasus (casestudy). Studi kasus adalah bentuk penelitianyang mendalamtentang suatu aspek lingkungan sosial termasuk manusia didalamnya. Sumberdata merupakan sumber dimana data dapat diperoleh. Pengumpulan data dalam penelitian kualitatif dilakukanpada naturalsetting (kondisi yang alami), sumber data primer, dan teknik pengumpulan data lebih banyakpada observasi terus terang atau tersamar, wawancara mendalam (indepth interview) dan dokumentasi. Sumber data yang digunakan dalam penelitian ini adalah:

1) Data primer, yaitu data yang diperoleh langsung melalui 
wawancara kepada mahasiswa semester IV Pendidikan Ekonomi Universitas Muhammadiyah Metro.

2) Data sekunder, yaitu data yang diperoleh secara tidak langsung melalui arsip, data dandokumen yang memiliki hubungan erat dengan permasalahan kajian penelitian. Dalam halini data sekunder didapatkan dari nilai mahasiswa.

Menurut Sugiyono (2013:297)

Istilah populasi dalam penelitian kualitatif dinamakan social situation atau situasi sosialyang terdiridari tiga elemen yaitu: tempat (place), pelaku (actors), dan aktivitas (activity) yang berinteraksi secara sinergis. Dalam penelitian kualitatif tidak menggunakan populasi, karena penelitian kualitatif berangkat dari kasus tertentu yang ada pada situasi sosial tertentu dan hasil kajiannya tidak akan diberlakukan ke populasi, tetapi ditransferkan ketempat lain pada situasi sosial yang memiliki kesamaan dengan situasi sosial pada kasusyang dipelajariSugiyono (2013:295).

Teknik sampling yang digunakan dalampenelitianini adalah Purposive sampling. Purposive sampling adalah teknik pengambilan sampel sumber data dengan pertimbangan tertentu. Pertimbangan ini, misalnya orang tersebutyang dianggappaling tahu tentang apa yang kita harapkan,atau dia sebagai penguasa sehingga akan memudahkan peneliti menjelajahi obyek/situasi sosial yang diteliti Sugiyono (2013:300).

Teknik pengumpulan data adalah wawancara, observasidan dokumentasi. Data yang dikumpulkan melalui wawancara adalah tentang:

1) Metode resitasiyang digunakan dalamproses pembelajaran.

2) Praktikum kegiatan koperasi

3) Evaluasi hasil pemberian treatment hasil pembelajaran

Teknik pemeriksaan data dalam penelitian ini menggunakan metode triangulasi sumber dan triangulasi metode. Hal ini dilakukan dengan membandingkan hasil dari pengamatan, wawancara, dan analisis dokumen. Diharapkan hasil akhir dari analisis mencapai tingkat mutu dan kevalidan yangtinggi.

Teknik analisis data yang digunakan dalam penelitian ini menggunakan pola penelitianin duktif yang diolah dengan teknik saling terjalin atau interaktif mengalir. Teknik data dalam penelitian ini mengikuti model analisis interaktif (Interactive ModelofAnalysis). Aktivitas dalam analisis data, yaitu reduksi data, penyajian data dan penarikan kesimpulan atau verifikasi. 


\section{PEMBAHASAN HASILPENELITIAN}

Mahasiswa pendidikan ekonomi yang mengambil mata kuliah koperasi adalah 67 orang. Mahasiswa ini dibagi menjadi dua kelas yaitu kelas A dan kelas B. Kelas A berjumlah 35 mahasiswa sedangkan kelas B berjumlah 32 mahasiswa. Dosen mempunyai peranan penting terhadap proses pembelajaran mahasiswa. Pada mata kuliah koperasi tugas dosen adalah menumbuhkan minat mahasiswa untuk berkoperasi.

Dosen merupakan salah satu sumber informasi dalam kegiatan perkuliahan. Ada berbagai sumber dalam kegiatan perkuliahan misalnya internet, buku teks bahkan teman sebaya. Namun, mahasiswa yang tidak mendapat bimbingan langsung dari dosen akan merasa kebingungan dalam belajar. Oleh karena itu, peran dosen diharapkan mampu mendampingi, membimbing dan mengarahkan mahasiswa dalam kegiatan pembelajaran.

Berdasarkan hasil observasi dan wawancara yang dilakukan diperoleh informasi bahwa mahasiswakurangnya minat mahasiswa untuk berkoprasi. Mahasiswa belajar mata kuliah koperasi hanya untuk sekedar menyelesaikan kewajiban pemenuhan angka kredit SKS saja. Padalahal salah satu tujuan dari mata kuliah ini adalah menarik minat mahasiswa untuk berkoprasi. Mahasiswa belum menyadari arti penting koperasi bagi perekonomian. Oleh karena itu tugas dosen adalah menarik minat mahasiswa untuk tertarik dalam kegiatan koperasi secara langsung baik dalam ruang lingkup mahasiswa maupun langsung berpartisipasi dalam koperasi yang ada di masyarakat.

Berdasarkan hasil penelitian, terungkap permasalahan yang dihadapi mahasiswa dalam pembelajaran mata kuliah koperasi yaitu kurangnya minat untuk mengaplikasikan ilmu atau teori yang telah didapat kedalam praktik nyata. Hal ini disbabkan karena kurangnya pemberia tugas terhadap maha kuliah ini. Oleh karena itu setelah ujian tengah semester dosen berinisiatif banyak memberikan tugas observasi langsung tentang koperasi-koperasi yang ada di masyarakat.

Kurangnya minat mahasiswa dalam mengaplikasikan teori ke dalam praktik langsung disiasati dengan pemberian tugas observasi dan melakukan wawancara terhadap koperasi di sekitar lingkungan mereka. Hal ini diharapkan dapat merangsang mahasiswa untuk dapat tertarik dan dapat menggali informasi langsung dari para praktisi dalam bidang koperasi. Dari permberian tugas observasi langsung dan wawancara ternyata 
mahasiswa menunjukkan respon yang positif. Ketika mahasiswa diminta mempertanggungjawabkan hasil observasi dan wawancara yang telah dilakukan ternyata mereka dengan lengkap dan antusias menceritakan hasil yang mereka peroleh. Hal ini menunjukkan minat mahasiswa untuk mengenal lebih jauh tentang koperasi semakin baik. Selain itu, pemberian tugas lainnya adalah mahasiswa diminta membuat sebuah Koperasi Simpan Pinjam (KSP) per kelas. Hasil dari rapat koperasi yang mereka buat sudah cukup baik dalam taraf pembelajaran awal. Mereka sudah dapat membuat berbagai peraturan yang harus dijalankan dalam koperasi yang mereka dirikan. Mereka telah melakukan rapat anggota untuk memusyawarahkan tentang aturan koperasi.

Pemberian tugas terhadap mahasiswa adalah salah satu yang harus dilakukan oleh seorang dosen. Karena dengan pemberian tugas ini diharapkan mahasiswa dapat mendalami teori yang telah dipelajari pada saat pembelajaran dikelas kemudian dapat dipelajari dan didalami ulang ketika mahasiswa mendapatkan tugas untuk pendalaman materi yang telah diberikan oleh dosen di kampus. Ketika mahasiswa hanya mendapatkan pembelajaran di kampus, mahasiswa hanya mengerti materi berdasarkan teorinya saja. Kemudian, jika mahasiswa diberikan tugas selain di kampus, mahasiswa pasti akan sendirinya berusaha mencari tahu bagaimana dapat mengerjakan tugas yang telah diberikan oleh dosen.

\section{KESIMPULAN}

Berdasarkan hasil penelitian yang telah dipaparkan maka dapat ditarik kesimpulan:

1. Pemberian tugas (resitasi) terhadap mahasiswa akan mempunyai dampak positif terhadap mahasiswa.

2. Pemberian tugas (resitasi) dengan cara observasi dan wawancara langsung terhadap praktisi koperasi dapat menarik minat mahasiswa untuk berkoperasi.

Berdasarkan hasil penelitian yang telah dipaparkan maka peneliti sarankan:

1. KSP (Koperasi Simpan Pinjam) yang telah dibuat mahasiswa perkelas diharapkan bukan hanya sebagai pemenuhan sks perkuliahan, namun dapat terus berlanjut sampai lulus kuliah.

2. KSP (Koperasi Simpan Pinjam) diharapkan dapat memperluas usahanya dan bukan hanya dalam bidang simpan pinjam, misalnya dapat memperluas usaha dalam bidang bisnis. 
e-ISSJN: $2442-9449$ Vol.4. No.1 (2016) 55-63

\section{DAFTAR PUSTAKA}

Djamarah dan Zain . 2013. Strategi Belajar Mengajar. Jakarta: Rineka Cipta.

Moleong, L. J.2007. Metodologi PenelitianKualitatif. Bandung:PT RemajaRosdakarya.

Sanjaya, Wina. 2010. Kurikulum dan Pembelajaran. Jakarta: Kencana.

Slameto. 2010. Belajar dan Faktor-Faktor yang Mempengaruhinya. Jakarta: PT Rineka Cipta.

Sugiyono.2013.Metode Penelitian Pendidikan Pendekatan Kuantitatif, Kualitatif, dan R\&D.Bandung: Alfabeta:

Surya, Mohamad. 2004. Psikologi Pembelajaran dan Pengajaran. Bandung: Pustaka Bani Quraisy. 
